\title{
South-South cooperation in health: bringing in theory, politics, history, and social justice
}

\author{
A cooperação Sul-Sul em saúde: trazendo \\ perspectivas teóricas, políticas, históricas e de \\ justiça social
}

Cooperación Sur-Sur en salud: aportando perspectivas teóricas, políticas, históricas y de justicia social

\author{
Anne-Emanuelle Birn 1 \\ Carles Muntaner 1,2 \\ Zabia Afzal 3
}

\begin{abstract}
Since the mid-2000s, the practice of South-South cooperation in health (SSC) has attracted growing attention among policymakers, health and foreign affairs ministries, global health agencies, and scholars from a range of fields. But the South-South label elucidates little about the actual content of the cooperation and conflates the "where" with the "who, what, how, and why". While there have been some attempts to theorize global health diplomacy and South-South cooperation generally, these efforts do not sufficiently distinguish among the different kinds of practices and political values that fall under the South-South rubric, ranging from economic and geopolitical interests to social justice forms of solidarity. In the spirit of deepening theoretical, historical, and social justice analyses of SSC, this article: (1) critically revisits international relations theories that seek to explain SSC, exploring Marxian and other heterodox theories ignored in the mainstream literature; (2) traces the historical provenance of a variety of forms of SSC; and (3) introduces the concept of social justice-oriented South-South.
\end{abstract}

South-South Cooperation; Social Justice; Global Health; Health Policy

\author{
Correspondence \\ A-E. Birn \\ Dalla Lana School of Public Health, University of Toronto. \\ 155 College St, Rm 558, Toronto, Ontario M5S 2L6, Canada. \\ ae.birn@utoronto.ca \\ 1 Dalla Lana School of Public Health, University of Toronto, \\ Toronto, Canada. \\ 2 Bloomberg Faculty of Nursing, University of Toronto, Toronto, \\ Canada. \\ 3 York University, Toronto, Canada.
}


Since the mid-2000s, the practice of South-South cooperation in health (SSC) - that is, state-state exchange of technical, financial, and human resources, and policy expertise and support among lowand middle-income countries 1 - has gained growing attention among policymakers, health and foreign affairs ministries, global health agencies, and scholars from a range of fields 2,3,4,5,6,7. While SSC is not new, its rising profile has coincided with two overlapping developments 8 . First is the renewed and renamed arena of global health diplomacy, which refers both to formal multilateral and bilateral decision-making around health and to the interaction between health and foreign policy concerns (such as "health security") involving negotiations and cooperation among a range of state and non-state actors 9,10,11,12,13,14. Second is the role of so-called BRICS countries (Brazil, Russia, India, China, and South Africa), whose global economic and political prominence has been accompanied by increasing SSC involvement, drawing notice from distinct quarters 15,16,17,18,19.

Given this attention, it is important to understand and characterize SSC in both theoretical and political terms. One assumption, frequently advanced by BRICS countries, is that SSC differs in form and orientation from North-South cooperation by the essence of its "Southern-ness" 20,21. Mobilizing their identity as formerly colonized, dominated, and "underdeveloped" countries, BRICS (except Russia) and other "Southern" donors present their efforts as countering the self-interested, hierarchical, and paternalistic cooperation that characterizes most North-South aid 18,22,23,24.

But the South-South moniker used to characterize the leadership in health cooperation by BRICS countries and actors as varied as Thailand and Saudi Arabia, not to mention Venezuela and Cuba, elucidates little about the content of SSC and conflates the "where" of health cooperation with the "who, what, how, and why". While there have been some attempts to theorize global health diplomacy and overall South-South cooperation, these efforts do not sufficiently distinguish, theoretically or politically, among the different kinds of practices and actions under the South-South umbrella 25,26,27. Most importantly, the SSC nomenclature does not take into account relationships of power and terms of engagement between so-called donors and recipients (neither historically dominant countries), the political, economic, and institutional nature of cooperation itself, and the motivations and values underpinning these exchanges 28. Without questioning whether SSC is a continuation of uneven power dynamics in the global (health) arena 29 or has truly distinct social justice dimensions, the term remains both apolitical and undertheorized 25.

In the spirit of bringing political, theoretical, historical, and social justice considerations into discussions of SSC, and based on conceptual deficiencies that we have identified in a comprehensive, multilingual review of the literature 30 , this article seeks to fill a gap in understanding of the complexity of SSC, particularly in relation to distinctions in its values and practices. First we revisit the dominant international relations theories that are typically employed to explain SSC, and supplement these with an exploration of Marxian and other heterodox theories ignored in the mainstream literature. We then illustrate the utility of these alternative theories in tracing the historical provenance of SSC, proposing the concept of social justice-oriented South-South cooperation (SJSSC) as a means of distinguishing among different forms of SSC and to enhance understanding of contemporary SSC practices.

\section{Theorizing SSC old wine, new bottles, or new world spirit?}

Though SSC is largely discussed in descriptive terms 31, some scholars are seeking to understand what motivates and explains engagement in SSC. Drawing on both mainstream and heterodox conceptions of power on the stage of world politics, they have examined SSC using international relations theories, symbolic capital, and counter-hegemonic solidarity. These theories are not specific to health but are often invoked to explicate health cooperation.

The dominant international relations theories, realism and liberalism, derive from Western capitalist contexts, arguably limiting their relevance to SSC. Realism considers international relations as a tool to advance national interests (state survival and security) and increase state power in an anarchical international system. Realism reduces all inter-state relations - putatively including SSC - to a struggle for military and economic ("hard") power, without attending to the range of nonmaterial driving forces such as ideological values and aspirations for international prestige ${ }^{32}$. Liberalism eschews 
the primacy of power struggles, emphasizing instead the role of liberal values (private property, civil liberties, etc.) and domestic non-state actors and priorities (e.g., "free trade") in shaping foreign policy goals. Liberalism, linked to idealist notions (e.g., humanitarianism), espouses inter-state cooperation 33. Institutionalism draws from both theories, recognizing the potential compatibility of self-interest and international cooperation. Constructivism holds that norms, beliefs, and agency transcend power politics and material motivations 34 but is less a theory than a way of understanding the factors and forces shaping foreign policy 35. Of these theories, realism has been most invoked in SSC.

With the waning of the Cold War and growing transnational interdependence, Joseph Nye theorized a shift in the exercise of state power in the realist account. He pointed out that it was no longer sufficient for states to advance their national interests through the tactics and instruments associated with a hard power approach. The traditional emphasis on military and economic coercion had become both costly and dangerous in this new context and had to be paired or replaced with more intangible aspects of power - what he called "soft power" - to more effectively acquire international leverage 36 . Nye influentially described soft power as the ability to use persuasion or cooptation via lower priority areas, especially culture, to shape the ideologies, preferences, and behaviors of other states 36 . Since its original formulation, this concept has been widely used by international relations scholars to analyze cooperation between states, including in relation to global health 37,38 .

While state, corporate, and philanthropic actors increasingly cite human rights, research partnerships, and development aid as elements of post-Cold War soft power, these activities continue to be driven in a one-sided manner, conferring considerable self-interest in terms of health security, political stability, and global market access 39 . More recently, the language of soft power has been adopted by various scholars 27 to frame SSC as championed by China 22 and especially Brazil 40,41.

On one hand, soft power language pushes the debate beyond normative assessments of whether a specific case of health cooperation is inspired by genuine altruism or national opportunism. The soft power approach highlights the strategic value and political nature of all global engagements, even those driven by a selfless and humanitarian impetus 42 . On the other hand, soft power constitutes yet another case of universalizing conceptual and methodological tools that are designed in terms of Western foreign policy experiences 43: the concept of soft power fails to capture the distinctive character of much South-South cooperation, even as certain SSC actors have themselves taken up the concept of soft power 44,45 .

In large part, this shortcoming stems from the inability of realism to analyze issues of power in close dialogue with the domestic circumstances and the particular international position of Southern countries that are often struggling to assert their autonomy in an unequal world system. As a result, the soft power designation may not adequately account for differences between the ethical orientations and values that inform Western imperialist powers' latitude to pursue soft power (even when hard power may loom in the background) and those that shape made by Southern countries to engage in SSC. Perhaps because of this conceptual inadequacy, scholars who study SSC often find themselves supplementing or substituting the explanatory value of soft power with social justice theories that emphasize the role of ethical commitments 46,47 and shared political interests 48 .

In this regard, soft power has also been combined with the related notion of "symbolic capital" to explain the foundation of Southern (especially Cuban) health diplomacy endeavors 49. Coined by French sociologist Pierre Bourdieu, symbolic capital refers to assets linked to social position, including prestige and legitimacy. In her studies of Cuba, Julie Feinsilver 46 (p. 85) argues that medical diplomacy is a form of "soft power politics" that helps to garner "symbolic capital - prestige, influence, and goodwill - which can translate into diplomatic support and material capital, such as trade or aid" 46 (p. 97). She suggests that this form of capital enables Cuba to defend its socialist system in the face of economic hardships and American imperialist threats. But this selective engagement and adoption of the language of soft power and symbolic capital - while possibly relevant to certain outcomes of Cuba's cooperation - does not fully capture the motivations behind it and applies realist theory in a contradictory manner to a state that is unable to assert power politics.

To be sure, not all scholars see the relevance of (neo-)realist thought for understanding the drivers of global health diplomacy in general and SSC in particular. Rejecting the characterization of Brazil's medical diplomacy as a form of soft power, Matthew Flynn 50 proposes that it embodies the country's social democratic principles. Similarly, Robert Huish 28 argues that the concept of "solidarity" more 
better captures Cuban experiences of reciprocity with its global health partners and its endeavors to create a "new political landscape of counter-hegemonic resistance". Huish's analysis is partly rooted in contemporary Marxist scholarship, which conceives of state power differently from the realist tradition 28. Scholars like Robert Cox 51 and Stephen Gill 52 cogently argue that the contemporary international system remains organized around a global capitalist order, making the distinctions between hard and soft power subsidiary to the larger political economy logic. Citing Antonio Gramsci's concept of "hegemony", they argue that it is through consent that this social order reproduces itself, and with it, the class relations underpinning global capitalism 51,52. In contrast to Joseph Nye's 53 characterization of soft power as an alternate means of achieving the same self-interested ends as hard power, Gramsci's analysis distinguishes between hegemonic and counter-hegemonic practices of power at the global level.

The Marxist tradition has also hosted debates on the question of sub-imperialism to understand foreign relations of Southern countries within the context of global capitalism. Originally developed by Brazilian economist Ruy Mauro Marini 54 in the 1960s, sub-imperialism refers to the contradictory politics of intermediary powers that depend on dominant forces to protect domestic and transnational elite and corporate interests yet remain semi-autonomous in foreign relations while retaining basic alignment with dominant powers. Applying this to the contemporary context, despite some shifts in class relations under the Workers' Party administrations (2003-2016), Brazil's foreign policy has largely been oriented to reinforcing global capitalist interests (and reproducing Brazilian elite interests therein) rather than representing a new form of social justice internationalism 55 . Medical diplomacy potentially serves as an exception, although it is not necessarily altruistic 6 . Patrick Bond 56 takes this argument a step further, arguing that not only do BRICS pursue pro-Western business interests, but their sub-imperialist features of domestic super-exploitation, land grabs, and military involvement entrench a global capitalist system based on neoliberalism and armed intervention. Fontes \& Garcia 57 argue that Brazil (like other Southern powers) is not sub-imperial but instead is part of a reconfiguration of imperial capitalism involving strong protagonism of the state. Here, the penetration of Brazilian transnational corporations, such as mining giant Vale - backed by the Brazilian state - does not enhance national (including labor) interests, as evidenced by curtailment of worker rights and a bitter strike in Vale's Canadian subsidiary even as Brazilian workers were laid off. Despite ambitions of solidarity by BRICS-led SSC, both sub-imperialist and imperial capitalist theories negate the possibility of BRICS operating outside global capitalist interests.

This begs the question of how else to theorize (and practice) anti-hegemonic alternatives to mainstream international relations. Modern socialist and anarchist theories envisage the possibility of egalitarian exchange in international relations fueled by the collective action of the oppressed 58 , deriving from proletarian internationalism tradition elaborated by Karl Marx, Rosa Luxemburg, and Vladimir Lenin, among others ${ }^{59}$. In the wake of the 1848 revolutionary uprisings across the world, and despite years of repression against those involved 60 , a movement for international working class solidarity was launched in the mid-1860s. This "First International" claimed allegiance of over one hundred organizations and hundreds of thousands of workers from many countries. The movement eventually dissolved amid infighting among anarchists, reformists, and Marx himself (who favored legislative struggles for workers' rights as a precursor to social revolution) and then was reborn as the decades-long "Second International" until nationalist sympathies trumped worker solidarity at the outbreak of World War I. A "Third International" arose with the Russian Revolution, succumbing to Soviet control under the Comintern 61.

Meantime, in Latin America, proletarian internationalism was vividly expressed in José Martís 1870s-1890s dual call for Cuban independence and transnational solidarity to stave off imperialism (an effort expressed earlier that century in the Bolivarian independence movement). These movements had lasting resonance for social justice-oriented country-to-country cooperation 62, including in recent configurations of inter-state collaboration, such as the Bolivarian Alternative for the Americas (ALBA).

Worldwide proletarian solidarity both informed and inspired leftwing medical cooperation, involving country-to-country exchanges, international medical support for revolutionary movements, and attempts to shape international organizations 63 . A notable example is the medical solidarity provided by health worker brigades from around the world to support democratic forces 
fighting fascism during the 1930s Spanish Civil War 64. While Latin American volunteers comprised an important contingent of medical internationalists to Spain, and Mao's revolutionary efforts also attracted health comrades, most famously Canadian physician Norman Bethune, these were not South-South efforts per se.

After World War II, state-state solidarity materialized in the context of decolonization struggles and socialist politics. Several other critical approaches sought to explain, and counter, the emergent development enterprise, favored by the US and capitalist interests. Dependency theory, articulated by André Gunder Frank among others, argued that the colonial system was replaced by an exploitative international division of capital, resources, and profits that forces peripheral former colonies into trade dependency (exchange of raw materials for manufactured imports) backed by repression, military power, and the complicity of peripheral elites. Undergirding this system is a semi-periphery, in Wallerstein's world-systems theory, engaged in both dimensions, along the way helping attenuate capitalism's contradictions. Dependency theorists emphasized self-reliance, government planning and ownership of industry, and agrarian collectivism; this proffered possibilities for SSC, but some assumed that rupturing core-periphery inequalities need not be accompanied by a complete break with capitalist interests, thereby potentially recreating asymmetries in SSC 65 . Post-colonial theory also decries the development paradigm for purporting aid generosity while entrenching North-South domination in alignment with expansion of global capitalism. Emphasizing cultural dimensions and discourse more than political and economic relations, the post-colonial critique lays analytic and rhetorical groundwork, if not concrete tools, for horizontal SSC 66 .

How this theoretical heterodoxy might be expressed in the practice of SSC has not always been evident. The USSR under Stalinist authoritarianism was often realist in its foreign policy actions seeking political alliances alongside building pharmaceutical plants and sponsoring massive fellowship programs. China's early international commitment to mass mobilization for the collective good has transitioned in recent years into a more realist approach of using health cooperation side by side with large-scale economic investment. Cuba's health cooperation, as we shall see, has perhaps most continually operated in the vein of proletarian internationalism, even resisting Soviet pressure to scale back its solidarity approach 47 .

With the neoliberal and militarist resurgence of recent decades, Cuba became a rather lonely proletarian internationalist actor, but the reconstruction of class power in the Third World against US/NATO imperialism 67 has brought new prospects, especially in Latin America. The Bolivarian revolution in Venezuela in 1998 was the hallmark of proletarian anti-imperial resistance, also heralding a new form of medical internationalism 68 . Yet proletarian internationalism may not adequately capture the full scope of this solidarity-oriented form of SSC. Various Latin American countries of the "pink tide" where center-left governments came to power in the 2000s (Argentina, Bolivia, Chile, Ecuador, El Salvador, Uruguay), as well as China, India, and South Africa, participate in some variants of health equity-informed SSC without necessarily reflecting proletarian internationalism traditions.

While opening certain explanatory avenues, this theoretical exploration does not sufficiently distinguish among the various forms of SSC in their contemporary guise.

\section{SSC: some historical threads from the Cold War era}

SSC's longest roots may be found in Latin America, which experienced decolonization over a century before African, Asian, and Caribbean independence (with the exception of Haiti, which in 1803 became an independent republic). The late 19th century's pan-American movement, largely forced on the region by the US, generated dialogue via regional conferences and professional interchanges in economic, social, cultural, and scientific spheres, albeit with the backdrop of US imperialism and domestic turmoil. Still, a limited form of progressive SSC began in the 1890s with sharing of scientific expertise, secondment of policymakers, and other forms of cross-country support around public health and political movements pushing for improved social conditions 69,70 . Specialized agencies, such as the Pan American Sanitary Bureau (PASB, today Pan American Health Organization - PAHO) and Uruguay's International American Institute for the Protection of Childhood ${ }^{71}$, also enabled some decentralized country-to-country policy sharing and advisement 72 . 
After World War II, North-South health cooperation (purveyed by the US, current/former colonial powers, and new imperial arrangements such as the Colombo Plan; later joined by Soviet bloc efforts) 73 - together with United Nations (UN) multilateralism - were consolidated as the heir to imperial health arrangements, with little apparent alternative. But political forms of SSC also flourished in terms of shared resistance to imperialism. The Global South networks generated by initiatives such as the 1927 World Congress against Imperialism and Colonial Oppression (the first meeting of the League against Imperialism, consciously named to scorn the League of Nations' refusal to recognize colonial self-determination) 74 served as important precursors tor later forms of solidarity, including liberation movements in Africa and Asia, revolutionary struggles in Latin America, and challenges to imperialism in formal UN venues 75 .

With many countries in shambles in the aftermath of violent liberation struggles and failing to upend colonial-era state-society political, economic, and social relations 76 , prospects emerged for countering neocolonialism in aid and forging a third global political force not compromised by the Cold War rivalry. The 1955 Bandung (Indonesia) Conference gathered leaders from newly decolonized nations of Africa, Asia, and the Middle East who sought to structure cooperation "on the basis of mutual interest and respect for national sovereignty" 77 (p. 95). Six years later, the Nonaligned Movement (NAM, countries affiliated neither with nor against the US-led Western bloc or the Soviet-led Eastern bloc) was created, and in 1964 the Group of 77 (now 134) countries was formed - the largest grouping within the UN. The G-77 began to advocate for the collective economic needs of its members, including fair terms of trade, a concern institutionalized through the UN General Assembly's Conference on Trade and Development (UNCTAD), and its principal project - the 1974 call for a New International Economic Order (NIEO).

Heavily resisted by the US and other powerful countries, the NIEO nonetheless helped shape ideas and efforts around social and economic justice 78 , including negotiation of a potent but doomed Code of Conduct by the UN's Commission on Transnational Corporations (1975-1992). While not directly connected to health cooperation, the NIEO both inspired and was invoked by the World Health Organization's (WHO's) call for social justice-oriented primary health care to replace technical disease campaigns at the 1978 Alma-Ata conference - a transformation widely supported in the 1970s but stymied by the neoliberal turn the following decade 79. By the 1990s, as the debt crisis swept across G-77 countries, the World Bank had not only upstaged WHO in the realm of health "cooperation", but it coopted both primary health care and poverty reduction efforts in the context of the Bamako Initiative's espousal of user fees and, especially, of several waves of structural adjustment loans with conditionalities imposing the downsizing of government health and social programs and the privatization of health services 80 .

The G-77, UNCTAD, and NAM were not focused on South-South cooperation so much as changing the rules of the (global trade, investment, and finance) game. Even so, these initiatives issued action programs favoring cooperation and contributed to a sense of leftist solidarity across the Global South. As an example, in the 1967 Arusha declaration, Tanzania's first post-colonial President Julius Nyerere declared his political party's aim "to build a socialist state" 74 . The urgency of Nyerere's call for nationalization of industry, resettlement of the scattered rural population into villages, and universal access to education and health care resonated widely 81 . China stepped in to cooperate 82 , sending several medical teams to Tanzania and constructing hospitals 22,83 alongside its commitment to build the $1,800 \mathrm{~km}$ long Tanzania-Zambia railway. Even before, China accepted newly independent Algeria's invitation to send a medical team in 1963, marking its first SSC mission. Thereafter, China cooperated with dozens of African countries 83,84, initially as a form of anti-imperial solidarity and stemming from its model of rural delivery of medical care using "barefoot doctors". Arranged at the level of Chinese province-country cooperation, Chinese SSC underwent a transformation in the 1970s, as it sought international support for its entry into the UN system and increased commercial ties following Mao's death and the country's shift to a market economy 22,85.

No country took on non-aligned, social justice-oriented health cooperation with greater commitment than Cuba, starting soon after its 1959 revolution. Even as half its own doctors were fleeing, Cuba sent a team of medics to earthquake-struck Chile in 1960, the beginning of a policy pairing prompt humanitarian relief with long-term commitments to Southern countries. In subsequent years, Cuba cemented its South-South cooperation on the basis of solidarity and gratitude toward 
countries that had supported the Cuban revolution. In 1963, despite the US embargo, Cuba sent 56 physicians to Algeria to help the newly independent country meet its enormous health needs after the violent liberation struggle from France ${ }^{46}$, succeeded by health cooperation and medical training in Vietnam, Mali, Congo, Guinea, and dozens more countries across Africa, Asia, and Latin America involving tens of thousands of Cuban medics 86 . Notably, Cuba's SSC did not purely involve socialist countries or revolutionary efforts, despite the views of Argentine physician and Cuban revolutionary Ernesto "Che" Guevara, then Cuba's Minister of Industry, who saw revolution as an extension of social medicine 87 .

In the 1970s South-South cooperation was taken up by the UN in an attempt to make the development project more "inclusive," but it responded to NIEO critiques only obliquely and underscored the technical, leaving out the political, dimensions of such cooperation. In 1974 the UN Development Programme set up a special unit for technical cooperation between developing countries, presaged in the Americas by the 1971 Hipólito Unanue Agreement on Health Cooperation between Andean Countries. In 1978 the Buenos Aires Plan of Action (BAPA) for Promoting and Implementing Technical Cooperation among Developing Countries, signed by 138 delegations and endorsed by the UN General Assembly, signaled such cooperation for "mutual benefit and for achieving national and collective self-reliance, which are essential for their social and economic development" 88 (p. 6). BAPA highlighted "strict observance of national sovereignty, economic independence, equal rights and non-interference in domestic affairs of nations" 88 (p. 8), regardless of size, political system, and economic conditions, also (vainly) insisting that such principles were relevant to all forms of cooperation.

Paradoxically, the meeting host, Argentina, was then governed by a repressive US-backed dictatorship - hardly a beacon for enlightened cooperation. Moreover, this effort took place on the eve of the Third World debt crisis, plunging most countries of the Global South into ever greater poverty and subject to structural adjustment loans compelling declines in government spending (including for overseas cooperation). As such, BAPA's implementation was constrained almost immediately by economic difficulties, as well as insufficient human resources, poor coordination, and reported "structural and cultural differences" 89 . Only China and Cuba managed to carry the SSC mantle into the 1990s, albeit along divergent routes. Still, BAPA's framing of the importance of self-reliance and capacity-building amid horizontal cooperation makes it a key reference point for contemporary SSC efforts 90,91.

One last episode from this era would prove important to the resurgence of SSC. In the 1980s, Nyerere (whose African socialist project was derailed by the debt crisis and International Monetary Fund policy prescriptions) moved to the international stage to spearhead the South Commission (and its 1990 report). Like BAPA, the South Commission called for mutual learning across the Global South, but the latter emphasized the need for a separate form of Southern development that rejected Northern prescriptions and exploitation ${ }^{92}$. While its critique was piercing, the Commission's recommendations were divided, with only a minority calling for collective well-being, rather than profitoriented growth, as a way forward. The dominant view was that larger countries should serve as "locomotives of the South" 93 , bringing along the smaller countries in their wake. These ideas later inspired the formation of the India-Brazil-South Africa group (IBSA) in 2003 and presaged the BRICS in 2006. But it was not clear where Nyerere's hopes would fit in.

\section{Towards a theory of SJSSC}

Fast forward 20 years and SSC has burgeoned from the proletarian internationalist practices of a few socialist countries during the Cold War period to the involvement of dozens of countries and a smaller contingent of sizable South-South donors operating in the context of considerable bilateral business investments. Overall South-South "development assistance," encouraged by another round of UN resolutions in the 2000s, has reached between USD 11 and USD 41.7 billion annually 94, tripling in recent years 95 . India purveys USD 700 million to over USD 2 billion per year, South Africa almost USD 150 million/year 96. Extrapolating from North-South patterns (Query Wizard for International Development Statistics. http://stats.oecd.org/qwids/, accessed on 27/Feb/2016), at least 25\% likely goes to health and humanitarian cooperation. 
China is currently the largest player, providing between USD 4 and USD 25 billion per year. It works mostly in Asia and Africa in areas of health, population, water, and sanitation (even as China itself is grappling with problems of water and air pollution and health services coverage) - with the majority of projects focusing on infrastructure and human resource development. As well, the USD 5 billion China-Africa Development Fund provides loans and credits to Africa, plus USD 2.8 billion in canceled debts. In 2015 China announced a new three-year USD 60 billion development and investment package to Africa 97. In Latin America and the Caribbean, China has also become a key source of loans, surpassing lending from the World Bank and Inter-American Development Bank combined, reaching USD 29 billion (plus almost USD 35 billion in credit) and totaling upwards of USD 125 billion since 2005 98. Critics have argued that China is not motivated by solidarity but by its quest for natural resources and to expand markets for its products 99 , a charge that is just as applicable, past and present, to high-income country donors, though questioned more among SSC donors.

Brazil, meanwhile, spent USD 160.3 million on SSC in 201094 in addition to in-kind technical cooperation for agriculture, education, and health. Brazil's priority regions are Latin America, the Caribbean, and Africa, particularly focusing on Portuguese-speaking African countries. Critical concerns have been raised about the coexistence of its bilateral cooperation and corporate interests, such as in Mozambique, where Brazil's mining and construction sectors have major investments 100. Brazil's SSC efforts have also been part of the Workers' Party's National Health Plan, involving training and promoting universal health systems 101. In that sense Brazil serves as an ambivalent, even contradictory, development model, purveying equity-oriented values in its domestic social policies (reducing poverty, expanding educational and health care access, promoting small business; all unraveling in the context of the global financial and commodities crisis and the domestic political crisis), simultaneous to aggressive pursuit of transnational corporate interests in commodities, agriculture, and foreign investment within a global capitalist system 102. A crucial issue remains whether the relative autonomy experienced by Brazil's SSC serves as an exception to its larger geo-economic goals 50,55 or enables them.

All told, we find that neither global health diplomacy - and its invocation of soft power - nor the passively descriptive SSC sufficiently explain the varieties of interaction, especially solidarity-oriented non-hegemonic cooperation, among formerly dominated countries. Yet proletarian internationalism also does not offer an adequate theoretical frame because it supposes solidarity around revolutionary struggles, which is not necessarily the case, as with Cuban medical solidarity. But humanitarian internationalism 47 , evoking liberalism's presumption of shared values, is also problematic given humanitarianism's association with charity and militarism 103. Even Brazil's high-minded "structural cooperation in health" involving "building capacity for development, integrating human resource training, organizational strengthening, and institutional development in the context of local resources, rather than passive one-way transfer of knowledge and technology" 90 (p. 25) does not perforce challenge the political and economic status quo.

As such, our proposed term, SJSSC, seeks to fill a conceptual niche: except in analyses of Cuba, social justice does not figure prominently in soft power rationales for SSC. SJSSC draws from emphasis on social rights, including legal obligations and constitutional protections for health-related human rights, and local participatory democracy in areas such as universal comprehensive health care. Key players include Cuba 104, and under certain instances Brazil, China, South Africa, and Venezuela 90,105,106. Various regional blocs also engage in SJSSC, such as ALBA, articulating Third World alliances linked with global civil society 107, and the Union of South American Nations (UNASUR), which also seeks "de-neoliberalization" via health diplomacy 108, but not IBSA, which has followed a top-down and mild approach 109.

The principles of SJSSC entail:

- Even terms of engagement, intent on reducing power and resource asymmetries between donor and recipient, elimination of "conditionalities," and explicit recognition of cooperation or mutual exchange (never "aid") 110;

- Counter-hegemonic values - promoting progressive political models; resisting corporate, capitalist, neoliberal interests 111 ; 
- Transformative aspirations, in building social infrastructure, training primary health care practitioners, supporting social rights, and working hand in hand with governments to build lasting and equitable provision of essential needs; and

- Community-based approaches, with priorities defined through local agenda-setting and local populations integral to shaping cooperative activities through their ideas, labor, and decision-making.

By comparison, the blanket term SSC offers scant explanatory rationale for why and how it differs from other forms of development aid. While it may be true that peoples with common histories of oppression are better able to identify and address their own population health problems without having to enter into the unequal power relationships inherent to North-South cooperation, this contention should not be taken at face value. There are also self-interested motives within SSC apparent in China's and Brazil's desire to raise their profile in international politics and become important players in multilateral organizations. These countries' goals, like their extractive interests in Africa, need to be scrutinized when assessing the nature of SSC health projects. China proudly refrains from imposing conditionalities around its cooperation and loans 112, but these efforts take place concurrent to primary resource extraction (oil and mining). Meanwhile, Brazil's commitment to "structural cooperation" focuses on country-determined needs rather than outside agenda-setting and involves long-term investment in infrastructure, local institution-building, and the social determinants of health ${ }^{90}$. For example, Brazil sends physicians and other health care personnel (e.g., lab technicians) to Portuguese-speaking countries in sub-Saharan Africa (such as Angola and Mozambique) to assist in the capacity-building of their HIV and tuberculosis programs ${ }^{6}$, and has established an ARV factory in Mozambique 45. Yet deep investments in mining and construction operate in parallel to health diplomacy 113. Nonetheless within Latin America, Brazil's leadership in UNASUR around disease surveillance, health human resources policy, universal health systems development, access to medications, and policy cooperation regarding social determinants of health and health promotion (including unified regional deliberations with WHO) has been carried out on more equal footing 108,114.

South-South cooperation that is truly social justice-oriented, guided by common political values around redistribution, social rights, shared power, and solidarity with social and political movements fighting for health equity, distinguishes SJSSC from prevailing models of global health cooperation. These more solidarity-inspired forms of SSC contesting the orthodox, self-interested, and "realist" geopolitical-economic forces propelling this field have been enabled by a confluence of factors, including the (re)election over recent decades of leftist parties on social redistribution, welfare regime-building, and social rights platforms 115,116, coupled with economic growth in certain large middle-income countries, such as Brazil and Venezuela. Within sub-Saharan Africa, too, growing interest in health diplomacy stresses regional unity, an ethic of liberation, and equitable forms of development 117 .

Although SJSSC activities incorporate features of other types of cooperation, such as health personnel training, human resources exchange, provision of health care equipment and infrastructure, drug production and distribution, and surgical interventions, there is also greater attention to primary health care and anti-hegemonic policy activism (such as against monopolistic patent protections) 50 .

Revisiting Cuba's longstanding protagonist role in SJSSC: since 1960 almost 140,000 Cuban medical professionals have served in over 100 countries, including South Africa, Haiti, Pakistan (after the disastrous 2005 earthquake), Angola, Guatemala, Bolivia, Vietnam and Sierra Leone (2014-2015 Ebola response). Historically, most countries it has helped, including Haiti, provided no payment or quid pro quo for services 86 , although this is starting to change, as with the 14,000 doctors contracted by Brazil in 2014 to provide primary care in underserved areas. Building on its training of tens of thousands of professionals in the nine new medical faculties it helped create and dozens of others it has supported, in 1999 the Cuban government founded the Latin American School of Medicine (ELAM) dedicated to increasing the number of low- and middle-income coutries doctors serving marginalized populations. Particularly intent on training those from minority and impoverished backgrounds, ELAM provides full scholarships on the condition that graduates return to practice in their home communities. To date, some 25,000 people from over 80 countries and dozens of ethnic backgrounds have graduated as physicians 118 . Currently there are more than 20,000 students from almost 120 countries enrolled in medical faculties across Cuba, including around 200 US students from low-income and racial minority backgrounds. This endeavor has been enabled by Cuba's large 
investment in physician training since the 1959 revolution ${ }^{47}$. In 2014, for example, approximately 50,000 Cuban health personnel were working in over 60 countries, "a larger workforce than the Red Cross, Médecins Sans Frontières, and UNICEF combined" 28 (p. 261).

Arguably, the best illustration of SJSSC in practice is Cuban cooperation with Venezuela's Misión Barrio Adentro (Inside the Neighborhood), established through an agreement between the late Presidents Fidel Castro and Hugo Chávez to "exchange" Cuban doctors for Venezuelan oil - filling reciprocal needs. Inaugurated in 2003 at the behest of the mayor and constituents of one of Caracas's poorest neighborhoods who were fed up with incessantly delayed government promises for health care and Venezuelan doctors' refusal to serve them, Misión Barrio Adentro turns the principles of global health cooperation upside down. Rather than an international agency selecting the activity and setting the terms of cooperation, community-level committees - now located throughout the country - host over 14,000 Cuban doctors and dentists to live in their neighborhoods and serve as their practitioners, following a principle of solidarity (at a popular level) and exchange (at the level of the state) instead of aid. These doctors are not privileged short-term consultants, but rather eat and sleep in the same shantytown dwellings where they practice.

Misión Barrio Adentro's "bottom-up" approach emphasizes participatory democracy and management spanning multiple domains, including housing, education, employment, and neighborhood improvement 119,120 . Over 3,200 popular health clinics were built in poor neighborhoods that had never before enjoyed such attention to their (health) needs. Access to primary care doubled, reaching near universality, and over 530 million medical consultations have been carried out under the program 121. In 2010 Venezuela's Bolivarian government began an ambitious program to train its own community physicians and reduce dependence on foreign doctors. By March 2015 almost 19,000 Venezuelan physicians had graduated with degrees in Integral Community Medicine and begun working with Misión Barrio Adentro. Amid ongoing political and economic turbulence, including an inconsistent economic policy and an economic war orchestrated by the country's social elite, the government remains committed to the program; still, Venezuela has been deeply affected by the global recession ending the commodities boom (the main source of government income) and boycotts by the domestic and global corporate class 122. Moreover, Misión Barrio Adentro faces the challenges of not being integrated with the existing state public health system (the two still operate mostly in parallel) and of funding community health workers, who currently work as volunteers 123 .

At its heart, nonetheless, Misión Barrio Adentro's heeding of SJSSC principles of symmetrical agenda-setting, resisting neoliberal capitalism, transformative cooperation, and a community-based approach, make this effort solidarity-oriented on an entirely different level from other SSC activities.

\section{Conclusion}

Shared experiences of colonial and economic domination of countries engaged in SSC is often understood to make them cognizant of, and able to redress, the shortcomings of dominant North-South forms of health and development aid. At minimum, SSC does not dictate the terms of cooperation, instead responding to national and local demands for greater equity. SSC has also been posed as an antidote to aid asymmetries and problems because "Southern" countries are considered to have similar governance and bureaucratic challenges 4, coupled with analogously complex health needs, enabling them to benefit from exchange of policy ideas, human resources, technology, and know-how.

BRICS and other recent Southern donors appear to be pursuing a novel paradigm of mutual assistance via progressive language around shared development and true partnership, but social justice paradigms are not systematically reflected in SSC 20. Presently, Cuba stands out - at times joined by Brazil, Venezuela, South Africa, and China - as moving beyond the rhetoric of solidarity to pursue bona fide SJSSC.

SJSSC differs from SSC in delinking health cooperation from standard realist (including soft power) foreign policy and commercial objectives, even as other foreign policy aims remain present: SJSSC derives from shared egalitarian ideology and aspirations for health and social well-being, not necessarily based on internationalism's revolutionary struggle, but on common, progressive, usually anti-capitalist values across like-minded peoples. This "solidarious political consciousness" 62 
is bolstered by the material nature of medical cooperation - offering concrete improvements in people's lives. Although SJSSC increasingly entails a monetary or material exchange, it is in no way a quid pro quo for facilitating corporate interests 124 . Perhaps most importantly, SJSSC is incompatible with neoliberalism and does not seek to resolve the contradictions of global capitalism to enable its endurance.

To be sure, SSC, especially as practiced by BRICS countries, may generate ambiguous motivations. In Brazil, many involved in the national health agency's cooperation are driven by SJSSC-like social democratic values 50, even as activities are nested within Brazil's sizable South-South capitalist investments and the country's foreign policy interests. That this tension cannot be satisfactorily resolved is evidenced in the 2016 downfall of the governing Workers' Party, which despite great strides in poverty alleviation did not manage to redistribute fiscal and political power, in all likelihood jeopardizing SJSSC prospects into the near future.

Indeed, for all its global health solidarity potential, SJSSC's flourishing period in Latin America is currently under threat 106,125. The global economic downturn has had a profound impact on commodity markets affecting the state revenues of key Latin American countries engaged in SSC. Thus, both SSC and SJSSC are at a turning point, offering an opportunity to see what elements will endure and which will have constituted a sideline to the pursuit of realist interests of capital accumulation in the Global South.

\section{Contributors}

A.-E. Birn took the lead on conceiving the framework, researching, and writing the article. C. Muntaner and Z. Afzal contributed to designing, researching and writing the article.

\section{Acknowledgments}

We are grateful to the anonymous reviewers for their stimulating, thoughtful, and thorough suggestions and to Mariajosé Aguilera for her editing expertise. Funding for this research was provided by the Canadian Institutes of Health Research (CIHR grant \# EOG-126976) Ethics Office. This funder had no other role in the writing of the article or in the decision to submit for publication, and the ideas expressed herein are the authors' alone. 


\section{References}

1. World Health Organization. WHO's work with countries: cooperation with countries. http:// www.who.int/country-cooperation/en/ (accessed on 01/Feb/2017).

2. Amin S. Global history: a view from the South. Cape Town: Pambazuka Press; 2010.

3. Aginam O. Global health governance, intellectual property and access to essential medicines: opportunities and impediments for South-South cooperation. Glob Health Gov 2010; 4:1-12.

4. Singh Puri H. Rise of the Global South and its impact on South-South cooperation. Washington DC: World Bank; 2010.

5. Carrillo Roa A, Santana JP. Regional integration and South-South cooperation in health in Latin America and the Caribbean. Rev Panam Salud Pública 2012; 32:368-75.

6. Santana JP, Garrafa V. Cooperação em saúde na perspectiva bioética. Ciênc Saúde Coletiva 2013; 18:129-37.

7. Riggirozzi P. Regionalism through social policy: collective action and health diplomacy in South America. Econ Soc 2014; 43:432-54.

8. Bliss KE. Key players in global health: how Brazil, Russia, India, China, and South Africa are influencing the game. Washington DC: Center for Strategic and International Studies; 2010.

9. Pan American Health Organization. International health: a North-South debate. Washington DC: Pan American Health Organization; 1992.

10. Adams V, Novotny T, Leslie H. Global health diplomacy. Med Anthropol 2008; 27:315-23.

11. Labonté R, Gagnon ML. Framing health and foreign policy: lessons for global health diplomacy. Global Health 2010; 6:14.

12. Feldbaum H, Michaud J. Health diplomacy and the enduring relevance of foreign policy interests. PLoS Med 2010; 7:e1000226.

13. Amorim C, Douste-Blazy P, Wirayuda H, Støre JG, Gadio CT, Pibulsonggram N. Oslo Ministerial Declaration - global health: a pressing foreign policy issue of our time. Lancet 2007; 369:1373-8.

14. Kickbusch I, Kökény M. Global health diplomacy: five years on. Bull World Health Organ 2013; 91:157-236.

15. Ruger JP, Ng NY. Emerging and transitioning countries' role in global health. St Louis U J Health Law Policy 2010; 3:253-89.

16. Tytel B, Callahan K. Shifting paradigm: how the BRICS are reshaping global health and development. New York: Global Health Strategies Initiatives; 2012.

17. Shen GC, Fan VY. China's provincial diplomacy to Africa: applications to health cooperation. Contemporary Politics 2014; 20:182-208.
18. Brown GW, Loewenson R, Modisenyane M, Papamichail A, Cinar B. Business as usual? The role of BRICS co-operation in addressing health system priorities in East and Southern Africa. Journal of Health Diplomacy 2015; 1:1-23.

19. Nayyar D. BRICS, developing countries and global governance. Third World Q 2016: 37:575-91.

20. Harmer A, Buse K. The BRICS - a paradigm shift in global health? Contemporary Politics 2014; 20:127-45.

21. Harmer A, Xiao Y, Missoni E, Tediosi F. 'BRICS without straw'? A systematic literature review of newly emerging economies' influence in global health. Global Health 2013; 9:15.

22. Youde J. China's health diplomacy in Africa. China (Singap) 2010; 8:151-63.

23. Buss PM, Ferreira JR, Hoirisch C. Health and development in BRICS countries. Saúde Soc 2014; 23:390-403.

24. Renzio P, Seifert J. South-South cooperation and the future of development assistance: mapping actors and options. Third World Q 2014; 35:1860-75.

25. Muhr T. Beyond 'BRICS': ten theses on SouthSouth cooperation in the twenty-first century. Third World Q 2016; 37:630-48.

26. Ruckert A, Labonté R, Lencucha R, Runnels V, Gagnon M. Global health diplomacy: a critical review of the literature. Soc Sci Med 2016; 155:61-72.

27. Kevany S. Global health diplomacy, 'smart power', and the new world order. Global Public Health 2014; 9:787-807.

28. Huish R. Why does Cuba 'care' so much? Understanding the epistemology of solidarity in global health outreach. Public Health Ethics 2014; 7:261-76.

29. Muntaner C, Ng E, Chung H. Making power visible in global health governance. Am J Bioeth 2012; 12:63-4.

30. Birn A-E, Afzal Z, Muntaner C. South-South health cooperation in/from Latin America: transformative social justice or continuity of dominant North-South aid patterns? In: Fourth Global Symposium on Health Systems Research. http://www.healthsystemsresearch. org/hsr2016/wp-content/uploads/posterabstract-book.pdf (accessed on 13/Feb/2017).

31. Saenz TW, Thorsteindottir H, Souza MC. Cuba and Brazil: an important example of SouthSouth collaboration in health biotechnology. MEDICC Rev 2010; 12:32-5.

32. Keohane RO, Nye JS. Power and interdependence: world politics in transition. Boston: Little Brown; 1977. 
33. Burchill S. Liberalism. In: Burchill S, Linklater A, Devetak R, Donnelly J, Nardin T, Paterson $\mathrm{M}$, et al., editors. Theories of international relations. 5th Ed. Basingstoke: Palgrave MacMillan; 2013. p. 57-87.

34. Finnemore M, Sikkink K. Taking stock: the constructivist research program in international relations and comparative politics. Annu Rev Polit Sci (Palo Alto) 2001; 4:391-416.

35. Slaughter A-M, Hale T. International relations, principal theories. In: Oxford Public International Law, editor. Max Planck encyclopedia of public international law. http://opil.ouplaw. com/oxlaw/search?conr=Slaughter,\%20AnneMarie (accessed on 13/Feb/2017).

36. Nye JSJ. Soft power. Foreign Policy 1990; (80):153-71.

37. Fijałkowski Ł. China's 'soft power' in Africa? J Contemp Afr Stud 2011; 29:223-32.

38. Bry S. The production of soft power: practising solidarity in Brazilian South-South development projects. Rev Can Etudes Dev 2015; 36:442-58.

39. Kassalow J. Why health is important to U.S. foreign policy. New York: Council on Foreign Relations/Milbank Memorial Fund; 2001.

40. Lee K, Gomez E. Brazil's ascendance: the soft power role of global health diplomacy. European Business Review 2011; 61-4.

41. Dauvergne P, Farias DBL. The rise of Brazil as a global development power. Third World Q 2012; 33:903-17.

42. Kirk JM. Cuban medical internationalism and its role in Cuban foreign policy. Diplomacy \& Statecraft 2009; 20:275-90.

43. Cabral L, Russo G, Weinstock J. Brazil and the shifting consensus on development cooperation: salutary diversions from the 'aideffectiveness' trail? Dev Policy Rev 2014; 32:179-202.

44. Buss P, Faid M. Power shifts in global health diplomacy and new models of development: South-South cooperation. In: Kickbusch I, Lister G, Told M, Drager N, editors. Global health diplomacy: concepts, issues, actors, instruments, fora and cases. New York: Springer; 2013. p. 305-22.

45. Carrillo Roa A, Silva FRB. Fiocruz as an actor in Brazilian foreign relations in the context of the community of Portuguese-speaking countries: an untold story. Hist Ciênc Saúde-Manguinhos $2015 ; 22: 153-69$.

46. Feinsilver J. Fifty years of Cuba's medical diplomacy: from idealism to pragmatism. Cuban Stud 2010; 41:85-104.

47. Kirk JM. Healthcare without borders: understanding Cuban medical internationalism. Gainsville: University Press of Florida; 2015.

48. De la Fontaine D, Seifert J. The role of SouthSouth cooperation in present Brazilian foreign policy: actors, interests and functions. Stockholm: Institute of Latin American Studies; 2010. (Stockholm Papers in Latin American Studies).
49. Feinsilver JM. Healing the masses: Cuban health politics at home and abroad. Berkeley: University of California Press; 1993.

50. Flynn M. Brazilian pharmaceutical diplomacy: social democratic principles versus soft power interests. Int J Health Serv 2013; 43:67-89.

51. Cox RW. Gramsci, hegemony and international relations: an essay in method. In: Gill S, editor. Gramsci, historical materialism and international relations. Cambridge: Cambridge University Press; 1993. p. 49-66.

52. Gill S, editor. Gramsci, historical materialism and international relations. Cambridge: Cambridge University Press; 1993.

53. Nye JSJ. Soft power: the means to success in world politics. New York: PublicAffairs; 2004.

54. Marini RM. World capitalist accumulation and sub-imperialism. Two Thirds 1978; 1:29-39.

55. Flynn M. Between subimperialism and globalization a case study in the internationalization of Brazilian capital. Lat Am Perspect 2007; 34:9-27.

56. Bond P. BRICS and the sub-imperial location. In: Bond P, Garcia A, editors. BRICS: an anticapitalist critique. London: Pluto Press; 2015. p. $15-26$

57. Fontes V, Garcia A. Brazil's new imperial capitalism. Socialist Register 2014; 50:300-20.

58. Harnecker M. A world to build: new paths toward twenty-first century socialism. New York: Monthly Review Press; 2015.

59. Lenin VI. On the national question and proletarian internationalism. Moscow: Novosti Press Agency; 1972.

60. Rapport M. 1848: year of revolution. New York: Basic Books; 2008.

61. Van der Linden M. Proletarian internationalism: a long view and some speculations. In: Wallerstein I, editor. The modern world-system in the longue durée. Boulder: Paradigm Publishers; 2004. p. 107-31.

62. Featherstone D. Solidarity: hidden histories and geographies of internationalism. London: Zed Books; 2012.

63. Brown TM, Birn AE. The making of health internationalists. In: Birn AE, Brown TM, editors. Comrades in health: U.S. health internationalists, abroad and at home. New Brunswick: Rutgers University Press; 2013. p. 15-42.

64. Palfreeman L. Spain bleeds: the development of battlefield blood transfusion during the Civil War. Eastbourne: Sussex Academic Press; 2015.

65. Leite IC. Cooperação Sul-Sul: conceito, história e marcos interpretativos. Observador OnLine 2012; 7:1-40.

66. Robledo C. New donors, same old practices? South-South cooperation of Latin American emerging donors. Bandung: Journal of the Global South 2015; 2:3.

67. Amin S. Capitalism in the age of globalization: the management of contemporary society. London: Zed Books; 1997. 
68. Muntaner C, Chung H, Mahmood Q, Armada F. History is not over: the Bolivarian revolution, "Barrio Adentro", and health care in Venezuela. In: Ponniah T, Eastwood J, editors. The revolution in Venezuela: social and political change under Chavez. Cambridge: Harvard University Press; 2011. p. 225-56.

69. Guy DJ. The Pan American Child Congresses, 1916 to 1942: Pan Americanism, child reform, and the welfare state in Latin America. J Fam Hist 1998; 23:272-91.

70. Almeida M. Circuito aberto: idéias e intercâmbios médico-científicos na América Latina nos primórdios do século XX. Hist Ciênc SaúdeManguinhos 2006; 13:733-57.

71. Birn AE. Uruguay's child rights approach to health: what role for civil registration? In: Breckenridge K, Szreter S, editors. Registration and recognition: documenting the person in world history. Oxford: Oxford University Press/British Academy; 2012. p. 415-47.

72. Cueto M. The value of health: a history of the Pan American Health Organization. Washington DC: Pan American Health Organization; 2007.

73. Rupprecht T. Soviet internationalism after Stalin: interaction and exchange between the USSR and Latin America during the Cold War. Cambridge: Cambridge University Press; 2015.

74. Prashad V. The darker nations: a people's history of the Third World. New York: The New Press; 2007.

75. Hatzky C, Stites Mor J. Latin American transnational solidarities: contexts and critical research paradigms. J Iber Lat Am Stud 2014; 20:127-40.

76. James CLR. Appendix: from Toussaint L'Ouverture to Fidel Castro. In: James CLR, editor. The Black Jacobins: Toussaint L'Ouverture and the San Domingo revolution. New York: Vintage Books; 1963. p. 391-418.

77. Slaugther A-M, Hale T. Final communiqué of the Asian-African Conference of Bandung [1955]. Interventions 2009; 11:94-102.

78. Whelan DJ. "Under the aegis of man": the right to development and the origins of the new international economic order. Humanity 2015; 6:93-108.

79. Dupuy E. Coalitions d'Etats du Sud: Retour de l'esprit de Bandung? Points de vue du Sud. Paris: Centre Tricontinental/Editions Syllepse; 2007.

80. Birn AE, Nervi L, Siqueira E. Neoliberalism redux: the global health policy agenda and the politics of cooptation in Latin America and beyond. Dev Change 2016; 47:734-59.

81. Lal P. African socialism and the limits of global familyhood: Tanzania and the new international economic order in sub-Saharan Africa. Humanity 2015; 6:17-31.
82. Ping A. From proletarian internationalism to mutual development: China's cooperation with Tanzania, 1965-95. In: Hyden G, Mukandala R, editors. Agencies in foreign aid: comparing China, Sweden and the United States in Tanzania. Basingstoke: MacMillan Press; 1999. p. 156-201.

83. Anshan L. Chinese medical cooperation in Africa: with special emphasis on the medical teams and anti-malaria campaign. Uppsala: Nordiska Afrikainstitutet; 2011.

84. Liang W, Wang Y, Cao G, Fan X, Jin N. China's approach in the blooming South-South health cooperation: chances, challenges and the way forward. Beijing: China National Health Development Research Center; 2014.

85. Wang K, Gimbel S, Malik E, Hassen S, Hagopian A. The experience of Chinese physicians in the national health diplomacy programme deployed to Sudan. Global Public Health 2012; 7:196-211.

86. Beldarraín Chaple E. La salud pública en Cuba y su experiencia internacional (1959-2005). Hist Ciênc Saúde-Manguinhos 2006; 13:709-16.

87. Guevara E. Discurso a los estudiantes de medicina y trabajadores de la salud. In: Ariet Garcia MC, Deutschmann D, editors. Che Guevara presente: una antología mínima. Melbourne: Ocean Press; 1960. p. 118-27.

88. United Nations. Buenos Aires plan of action for promoting and implementing technical cooperation among developing countries. Buenos Aires: United Nations; 1978.

89. United Nations. Report of the high-level committee on the review of technical cooperation among developing countries. New York: United Nations; 1997.

90. Almeida C, Pires de Campos R, Buss P, Ferreira JR, Fonseca LE. A concepção brasileira de "cooperação Sul-Sul estruturante em saúde". RECIIS (Online) 2010; 4:23-32.

91. Santana JP. Um olhar sobre a cooperação SulSul em saúde. Ciênc Saúde Coletiva 2011; 16:2993-3002.

92. Gosovic B. The resurgence of South-South cooperation. Third World Q 2016; 37:733-43.

93. Prashad V. The poorer nations: a possible history of the Global South. Brooklyn: Verso Books; 2013.

94. Open Data for International Development. Tracking underreported financial flows. http://aiddata.org/track-emerg ing-donors\#nondac_donors (accessed on 01/Nov/2016) 
95. United Nations Conference on Trade and Development. The least developed countries report 2014. Growth with structural transformation: a post-2015 development agenda. Geneva: United Nations Conference on Trade and Development; 2014.

96. Dornsife C. BRICS countries emerging as major aid donors. Asia Pathways 2013; 25 oct. http://www.asiapathways-adbi.org/2013/10/ brics-countries-emerging-as-major-aiddonors/.

97. Agutamba K. Africa: how will Rwanda benefit from China's \$60bn aid to Africa? http://www. focac.org/eng/zxxx/t1326327.htm (accessed on $01 /$ Nov/2016).

98. Gallagher KP, Myers M. China-Latin America finance database. Washington DC: InterAmerican Dialogue; 2015.

99. Liu P, Guo Y, Qian X, Tang S, Li Z, Chen L. China's distinctive engagement in global health. Lancet 2014; 384:793-804.

100. Marshall J. The worst company in the world. Jacobin 2015; (19). https://www.jacobinmag.com/2015/11/vale-corporation-brazilmining-lula-mozambique-brics.

101. Santos RF, Cerqueira MR. South-South cooperation: Brazilian experiences in South America and Africa. Hist Ciênc Saúde-Manguinhos 2015; 22:23-47.

102. Rousseff D. Brazil's view on global economic and environmental governance. In: Kirton J, Koch M, editors. The G20 Mexico Summit 2012: the quest for growth and stability. London: Newsdesk Media Group; 2012. p. 25-7.

103. Hutchinson JF. Champions of charity: war and the rise of the Red Cross. Boulder: Westview Press; 1996.

104. Huish R. Where no doctor has gone before. Waterloo: Wilfrid Laurier University Press; 2013.

105. Vickers B. Towards a new aid paradigm: South Africa as African development partner. Cambridge Review of International Affairs 2012; 25:535-56.

106. Ayllón Pino B. La cooperación Sur-Sur en América Latina y Caribe: de una época dorada a una fase incierta. Buenos Aires: Coordinadora Regional de Investigaciones Económicas y Sociales; 2015. (Anuario de la Integración Regional de América Latina y el Caribe, 11).

107. Artaraz K. New Latin American networks of solidarity? ALBA's contribution to Bolivia's National Development Plan (2006-10). Glob Soc Policy 2011; 11:88-105.

108. Herrero MB, Tussie D. UNASUR health: a quiet revolution in health diplomacy in South America. Glob Soc Policy 2015; 15:261-77.

109. Carrillo Roa A. A agenda de Cooperação SulSul em Saúde do Fórum IBAS - Índia, Brasil e África do Sul [Masters Thesis]. Rio de Janeiro: Escola Nacional de Saúde Pública Sergio Arouca, Fundação Oswaldo Cruz; 2014.
110. Corrales J. Using social power to balance soft power: Venezuela's foreign policy. Wash Q 2009; 32:97-114.

111. Ojeda Medina T. Cuba, 50 años de solidaridad con el sur. In: Ayllón B, Surasky J, editores. La cooperación sur-sur en Latinoamérica. Madrid: La Catarata; 2010. p. 132-55.

112. Information Office of the State Council. Preamble of white paper on China's foreign aid. Beijing: Information Office of the State Council; 2014.

113. Ventura D. Public health and Brazilian foreign policy. SUR - International Journal on Human Rights 2013; 10:95-113.

114. Buss PM, Ferreira JR. Cooperação e integração regional em saúde na América do Sul: a contribuição da Unasul-Saúde. Ciênc Saúde Coletiva 2011; 16:2699-711.

115. Fleury S. What kind of social protection for what kind of democracy? The dilemmas of social inclusion in Latin America. Soc Med 2010; 5:34-49.

116. Mahmood Q, Muntaner C. Politics, class actors, and health sector reform in Brazil and Venezuela. Glob Health Promot 2013; 20: 59-67.

117. Loewenson R, Modisenyane M, Pearcey M. African perspectives in global health diplomacy. Journal of Health Diplomacy 2014; 1:1-20.

118. Escuela Latinoamericana de Medicina. La ELAM en la historia de la medicina. http:// instituciones.sld.cu/elam/historia-de-la-elam/ (accessed on 10/Jul/2016).

119. Muntaner C, Armada F, Chung H, Rosicar M, Williams-Brennan L, Benach J. Venezuela's Barrio Adentro: participatory democracy, South-South cooperation and health care for all. Social Medicine 2008; 3:232-46.

120. Mahmood Q, Muntaner C, del Valle Mata León R, Perdomo RE. Popular participation in Venezuela's Barrio Adentro health reform. Globalizations 2012; 9:815-33.

121. Walker C. Venezuela's health care revolution. Halifax: Fernwood Publishing; 2015.

122. Bolton P. The other explanation for Venezuela's economic crisis. Washington, DC: Council on Hemispheric Affairs; 2016.

123. Cooper A. What does health activism mean in Venezuela's Barrio Adentro program? Understanding community health work in political and cultural context. Ann Anthropol Pract $2015 ; 39: 58-72$.

124. Romero A. Cuba, su política exterior y la nueva arquitectura de gobernanza regional en América Latina y el Caribe. Pensamiento Propio 2015; 20:107-34.

125. Petras J, Veltmeyer H. What's left in Latin America? Regime change in new times. Abingdon: Routledge; 2016. 


\section{Resumo}

Desde meados da primeira década do século XXI, a cooperação Sul-Sul em saúde (CSS) vem atraindo cada vez mais atenção entre gestores, ministérios da saúde e das relações exteriores, agências de saúde global, e pesquisadores de diversas disciplinas. Não obstante, o uso do termo "Sul-Sul" para caracterizar essa prática explica pouco sobre o conteúdo da cooperação, além de misturar o "onde?" com o "quem, quê, como e por quê?". Já houve algumas tentativas de teorizar a diplomacia da saúde global e a cooperação Sul-Sul geralmente, mas esses esforços têm sido insuficientes no sentido de distinguir as diversas práticas e valores politicos sob a rubrica Sul-Sul, desde os intereses econômicos e geopoliticos até a solidariedade e a justiça social. No espírito de aprofundar as análises políticas, teóricas, históricas, e de justiça social nas discussões sobre a CSS, o artigo: (1) revisita criticamente as teorias de relações internacionais que podem explicar a CSS, explorando teorias en la tradição Marxista e heterodoxas ignoradas na literatura convencional; (2) identifica as origens históricas das diferentes formas dessa cooperação; $e$ (3) introduz o conceito da cooperação Sul-Sul orientada a la justiça social.

Cooperação Sul-Sul; Justiça Social; Saúde Global; Politica de Saúde

\section{Resumen}

Desde mediados de los años 2000, la práctica de la cooperación Sur-Sur en salud (CSS) ha recibido una creciente atención entre formuladores de politicas, ministerios de salud $y$ de asuntos exteriores, organismos internacionales de salud y académicos provenientes de un gran abanico de campos científicos. Sin embargo, la denominación cooperación Sur-Sur poco dilucida acerca del contenido real de la cooperación y mezcla el "dónde" con el "quién, qué, cómo, y el por qué. A pesar de que han habido algunos intentos de teorizar sobre la diplomacia en la salud global y la cooperación Sur-Sur en general, estos esfuerzos no han identificado de manera suficiente los distintos tipos de prácticas y los diferentes valores politicos que caen en la rúbrica de CSS, y que incluyen desde los intereses económicos y geopoliticos hasta las formas de solidaridad fieles a la justicia social. Con el ánimo de ahondar en los análisis políticos, teóricos, históricos y de justicia social de la CSS, este artículo: (1) vuelve a examinar críticamente las teorías sobre las relaciones internacionales que intentan explicar la CSS, explorando teorías en la tradición Marxista y otras teorías heterodoxas, que han sido ignoradas en la literatura convencional; (2) rastrea los orígenes históricos de distintas formas de CSS; y (3) presenta el concepto de cooperación Sur-Sur orientada por la justicia social.

Cooperación Sur-Sur; Justicia Social; Salud Global; Política de Salud
Submitted on 11/Nov/2016

Final version resubmitted on 03/Feb/2017 Approved on 08/Mar/2017 